\title{
Effluent Monitoring Quality Assurance Project Plan for Radioactive Airborne Emissions Data
}

\author{
T. P. Frazier
}

Date Published

December 1995

Prepared for the U.S. Department of Energy

Assistant Secretary for Environmental Management

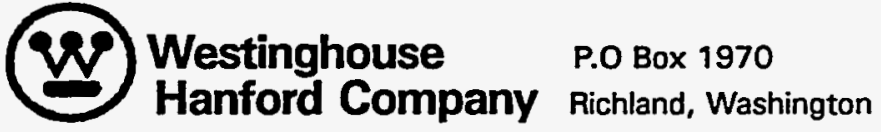

Management and Operations Contractor for the

U.S. Department of Energy under Contract DE-AC06-87RL10930

Approved for public release; distribution is unlimited 


\section{RELEASE AUTHORIZATION}

Document Number: HHC-EP-0528, Rev. 2

Document Title: Effluent Monitoring Quality Assurance Project Plan for Radioactive Airborne Emissions Data

Release Date: $\quad 12 / 20 / 95$

This document was reviewed following the procedures described in WHC-CM-3-4 and is:

APPROVED FOR PUBLIC RELEASE

WHC Information Release Administration Specialist:

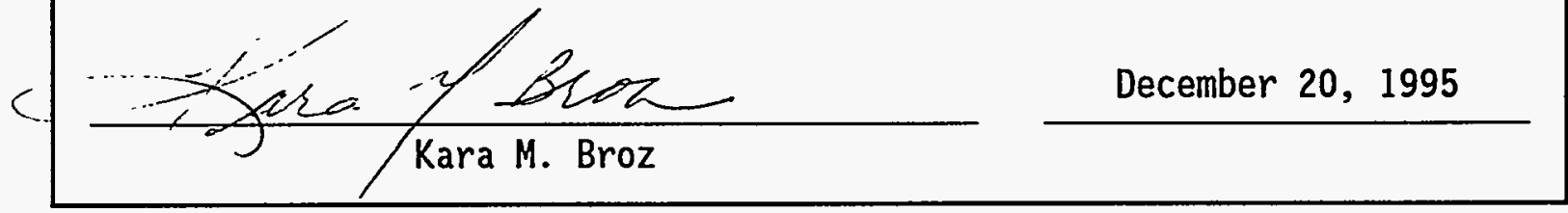


WHC-EP-0528-2

TITLE EFFLUENT MONITORING QUALITY ASSURANCE PROJECT PLAN FOR RADIOACTIVE AIRBORNE EMISSIONS DATA

Prepared by:

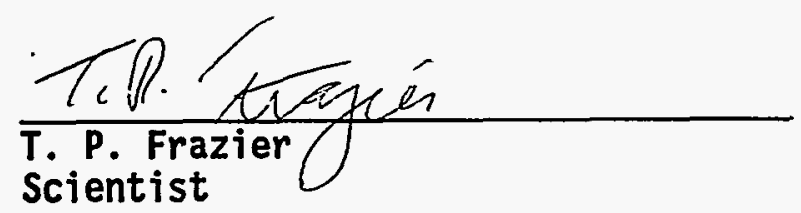

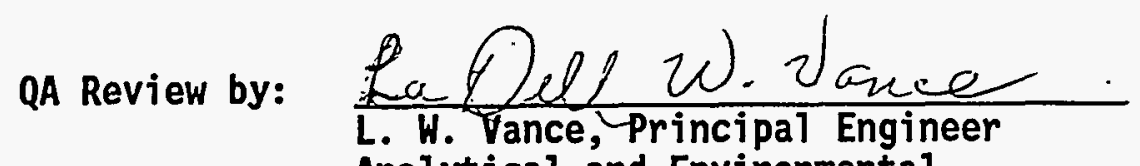
Analytical and Environmental Quality Assurance

Approved by:

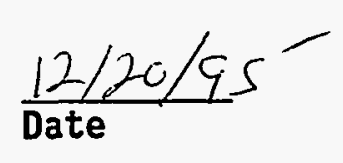

$\frac{12 / 20 / 95}{\text { Date }}$ $\frac{12-20-95}{\text { Date }}$

L. P. Diediker, Manager

Effluent Monitoring 



\title{
EFFLUENT MONITORING QUALITY ASSURANCE PROJECT PLAN
}

FOR RADIOACTIVE AIRBORNE EMISSIONS DATA

\begin{abstract}
This Quality Assurance Project Plan addresses the quality assurance requirements for compiling Hanford Site radioactive airborne emissions data. These data will be reported to the U.S. Environmental Protection Agency, the U.S. Department of Energy, and the Washington State Department of Health. Hanford Site radioactive airborne emissions are reported to the U.S. Environmental Protection Agency in compliance with Title 40, "National Emissions Standards for Hazardous Air Pollutants," Subpart H, "National Emissions Standards for Emissions of Radionuclides Other Than Radon From Department of Energy Facilities," Code of Federal Regulations, Part 61 (EPA 1989). Reporting to the U.S. Department of Energy is performed in compliance with requirements of U.S. Department of Energy Order 5400.1, General Environmental Protection Program (DOE 1988). Reporting to the Washington State Department of Health is performed in compliance with requirements of Hashington Administrative Code 246-247, "Radiation Protection-Air Emissions."
\end{abstract}

Effluent Monitoring performs compliance assessments on radioactive airborne sampling and monitoring systems in accordance with the Westinghouse Hanford Company Environmental Compliance Manual, WHC-CM-7-5. This Quality Assurance Project Plan is prepared in compliance with the Interim Guidelines and Specifications for Preparing Quality Assurance Project P1ans, QAMS-005/80 (EPA 1983), and "Quality Assurance Methods," 40 Code of Federal Regulations, Part 61, Appendix B, Method 114 (EPA 1989). 
WHC-EP-0528-2

This page intentionally left blank. 
WHC-EP-0528-2

\section{CONTENTS}

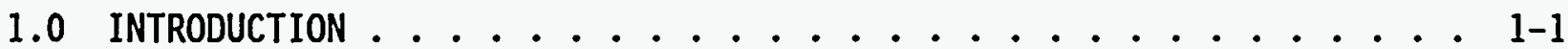

2.0 PROJECT DESCRIPTION ....................... 2-1

2.1 GENERAL OBJECTIVES .......................... $2-1$

2.2 EFFLUENT MONITORING RADIOACTIVE AIRBORNE EMISSIONS ACTIVITIES . 2-2

2.3 APPLICABILITY TO WESTINGHOUSE HANFORD COMPANY QUALITY ASSURANCE PROGRAM ...................... 2-2

2.4 MINIMUM QUALITY ASSURANCE REQUIREMENTS ......... 2-3

3.0 PROJECT ORGANIZATION AND RESPONSIBILITIES ........... 3-1

3.1 PROJECT MANAGEMENT .................... 3- .

3.1.1 Effluent Monitoring ............. 3-1

3.1.2 Effluent Monitoring Data Management. ....... 3-1

3.1.3 Effluent Monitoring Reporting ........... 3-2

3.2 SUPPORTING ORGANIZATIONS ................. 3-2

3.2.1 Westinghouse Hanford Health Physics Personnel .... 3-2

3.2.2 Hestinghouse Hanford Analytical and Environmental

Qual ity Assurance ............ 3-2

3.2.3 Hestinghouse Hanford Compliance Assurance . . . . . . 3-2

3.2.4 Westinghouse Hanford Facility Cognizant Engineers ... 3-3

3.2.5 Westinghouse Hanford Process Analytical Laboratory . . . 3-3

3.2.6 Pacific Northwest National Laboratory,

Health Physics . . . . . . . . . . . 3-3

3.2.7 Pacific Northwest National Laboratory,

Laboratory Safety Department, Environmental Compliance

Section ..................... 3

3.2.8 Pacific Northwest National Laboratory

Chemistry and Analysis .......... 3-4

3.2.9 Pacific Northwest Laboratory - Analytical

Laboratory Technical Administration . . . . . . . 3-4

3.2.10 Bechtel Hanford Incorporated .......... . 3-4

4.0 QUALITY ASSURANCE OBJECTIVES FOR MEASUREMENTS . . . . . . . . 4-1

4.1 ANALYTES OF INTEREST AND ANALYTICAL METHOD SELECTION $\ldots . .44$

4.2 REPRESENTATIVENESS, COMPLETENESS, AND COMPARABILITY . . . . 4-2

5.0 SAMPLING PROCEDURES ................... . . . .

5.1 SAMPLING PROCEDURES . . . . . . . ..... $5-1$

5.2 SUPPORTING PROCEDURES . . . . . . . . .... $5-1$

5.3 PROCEDURE APPROVALS AND CONTROL ............ 5-1

5.4 PROCEDURE ADDITIONS AND CHANGES ............ 5-1

5.5 SAMPLING SCHEDULE ................. 5-1

5.6 SAMPLING SYSTEM DESIGN .............. 5-2

6.0 SAMPLE CUSTODY ...................... 6-1

7.0 CALIBRATION PROCEDURES ................. 7-1

8.0 ANALYTICAL PROCEDURES .................. 8-1 


\section{CONTENTS (continued)}

9.0 MONITORING AND REPORTING CRITERIA . . . . . . . . . . 9-1

10.0 DATA REDUCTION, VERIFICATION AND REPORTING ......... 10-1

10.1 DATA REDUCTION . . . . . . . . . . . . . . 10-1

10.2 DATA VERIFICATION .................. 10-1

10.3 DATA REPORTING .................. . . . . . . . 10.3.1 Effluent Information System/Onsite Discharge

Information System Report ........... 10-2

10.3.2 Hanford Site Environmental Report . . . . . . . . 10-3

10.3.3 Air Emissions Report ............. 10-3

10.3.4 Environmental Release Report ........... 10-3

11.0 INTERNAL QUALITY CONTROL ................... . . . . .

12.0 PERFORMANCE AND SYSTEM AUDITS . . . . . . . . . . 12-1

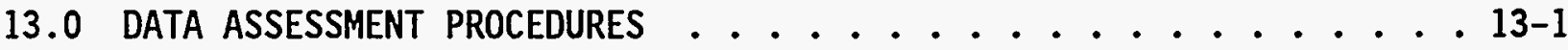

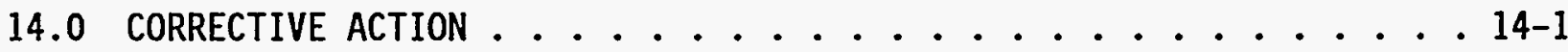

15.0 QUALITY ASSURANCE REPORTS . . . . . . . . . . 15-1

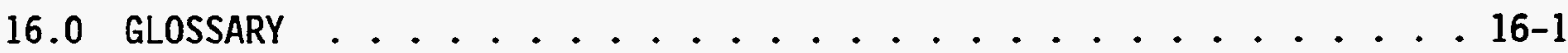

17.0 REFERENCES . . . . . . . . . . . . . 17-1 
WHC-EP-0528-2

\section{LIST OF TABLES}

3-1 Organizational Responsibilities for Radioactive Airborne Emissions Data Compilation and Reporting ......... 3-5

4-1 Radionuclides Requiring Routine Analyses . . . . . . . . . . 4-3

5-1 Supporting Procedures for Radioactive Airborne Emissions Sample Collection, Data Compilation, Calculation and Reporting

\section{LIST OF TERMS}

$\begin{array}{ll}\text { ABCASH } & \text { Automated Bar Coding of Air Samplers at Hanford } \\ \text { AEQA } & \text { Analytical and Environmental Quality Assurance } \\ \text { ALTA } & \text { Analytical Laboratory Technical Administration } \\ \text { BHI } & \text { Bechtel Hanford Incorporated } \\ \text { CFR } & \text { Code of Federal Regulations } \\ \text { CQL } & \text { contractual quantitation limit } \\ \text { DCG } & \text { derived concentration guide } \\ \text { DOE } & \text { U.S. Department of Energy } \\ \text { EDE } & \text { effective dose equivalent } \\ \text { EDP } & \text { electronic data processing } \\ \text { EM } & \text { Effluent Monitoring } \\ \text { EIS/ODIS } & \text { Effluent Information System/Onsite Discharge } \\ \text { EPA } & \text { Information System } \\ \text { ERS } & \text { U.S. Environmental Protection Agency } \\ \text { INEL } & \text { Environmental Release Summary } \\ \text { MEI } & \text { Idaho National Engineering Laboratory } \\ \text { MRP } & \text { maximal7y exposed individual } \\ \text { NESHAP } & \text { Management Requirements and Procedures } \\ \text { Northwest } & \text { "National Emission Standards for Hazardous Air } \\ \text { Laboratory } & \text { Pollutants" } \\ \text { QA } & \text { Pacific Northwest National Laboratory } \\ \text { QAPjP } & \text { Quality Assurance } \\ \text { QAPP } & \text { Quality Assurance Project Plan } \\ \text { QC } & \text { Quality Assurance Program Plan } \\ \text { QR } & \text { Quality Control } \\ \text { V/B } & \text { quality requirement } \\ \text { Westinghouse Hanford } & \text { Wentilation and Balance } \\ \text { WHC } & \text { Westinghouse Hanford Company } \\ \text { WSCF } & \text { Waste Sampling and Characterization Facility } \\ & \end{array}$




\section{WHC-EP-0528-2}

This page intentionally left blank. 
WHC-EP-0528-2

\section{EFFLUENT MONITORING QUALITY ASSURANCE PROJECT PLAN FOR RADIOACTIVE AIRBORNE ENISSIONS DATA}

\subsection{INTRODUCTION}

Title 40, Code of Federal Regulations (CFR), Part 61, "National Emissions Standards for Hazardous Air Pollutants" (NESHAP), Subpart $H$, "National Emissions Standards for Emissions of Radionuclides Other Than Radon From Department of Energy Facilities," Section 61.94(a) requires that owners or operators of U.S. Department of Energy (DOE) facilities provide annual monitoring reports and dose calculation results for radioactive airborne emissions from the previous year to the U.S. Environmental Protection Agency (EPA) Headquarters and regional offices by June 30 of each calendar year. At the Hanford Site, activities associated with this report can be further categorized as follows:

- Identification of point sources emitting airborne radionuclides

- Collection of representative stack and vent samples for analyses, performed by operating and waste management organizations responsible for routine operation of reactor facilities, chemical separations facilities, laboratories, tank farms, and their associated support buildings

- Measurement of stack and vent air flows

- Analyses of air samples collected from airborne streams, performed by DOE-approved 1aboratories onsite in the 200 and 300 Areas and offsite using established methods for radioanalyses

- Data collection, verification, compilation, calculation, and reporting of radioactive airborne emissions, performed by the Effluent Monitoring (EM) function within Westinghouse Hanford Company (Westinghouse Hanford)

- Dose calculations, performed by Pacific Northwest National Laboratory (Northwest Laboratory) using EPA-approved code; dose calculations are reviewed by the Hanford Site Dose Overview Panel.

This Quality Assurance Project Plan (QAPjP) addresses the quality assurance activities associated with the data collection and reporting activities. Other plans (i.e., QAPjPs and facility effluent monitoring plans) are the responsibilities of the facilities that support the other five activities listed above, except for the dose calculations, which are performed by Northwest Laboratory. 
WHC-EP-0528-2

This page intentionally left blank. 
WHC-EP-0528-2

\subsection{PROJECT DESCRIPTION}

\subsection{GENERAL OBJECTIVES}

The general objectives of the radioactive airborne emissions data collection, verification, compilation, and reporting activity are as follows:

- Report radioactive airborne emissions activity from Hanford Site discharge points to the DOE Effluent Information System/Onsite Discharge Information System (EIS/ODIS) located at Idaho Falls, Idaho, in accordance with DOE Order 5400.1, General Environmental Protection Program (DOE 1988)

- Provide summary emissions release data from all Westinghouse Hanford facilities for incorporation in the annual Hanford Site Environmental Report prepared by Northwest Laboratory, and for use by Northwest Laboratory in modeling the dose to the public from Hanford Site operations as required in DOE Order 5400.1 (DOE 1988)

- Report releases of airborne radioactivity from the Hanford Site, and the subsequent effective dose equivalent (EDE) to the hypothetical maximally exposed individual (MEI), to the EPA in compliance with 40 CFR 61 , Subpart H (EPA 1989) annual reporting requirements

- Report radioactive airborne emissions in the annual environmental release report prepared by Westinghouse Hanford for those facilities co-operated by the contractor, per requirements of DOE Order 5400.1 (DOE 1988)

- Provide facility management, with quantified data on releases from ongoing facility operations, by using a structured data collection and trend reporting method.

The collection, verification, compilation, and calculation of radioactive airborne emissions data is the final step in a formal process in which samples are collected from selected stacks and vents on the Hanford Site, and analyzed in onsite and offsite laboratories for radioactive materials present. The sample data are verified, and compiled for reporting to EPA and DOE. These activities began before 40 CFR 61, Subpart H (EPA 1989) was estab7ished to satisfy reporting requirements contained in DOE orders, and are mandated by the Hanford Federal Facility Agreement and Consent Order (Ecology et al. 1990) to continue until all sources of airborne radioactivity on the Hanford Site are el iminated.

A quality assurance program plan (QAPP) was prepared by the Waste Sampling and Characterization Facility (WSCF) Laboratory to support compliance with Subpart H. A QAPP is in place at International Technology Analytical Services and the Northwest Laboratory 325 Laboratory. Substantial information on the conduct of analyses at these laboratories is provided in WHC-EP-0536-2, Appendix H (WHC 1995a). 


\subsection{EFFLUENT MONITORING RADIOACTIVE AIRBORNE EMISSIONS ACTIVITIES}

The general categories of activities specific to the radioactive airborne emissions data activity are as follows:

- Collection of laboratory analyses performed to detect the presence of radioactive materials on particulate filter media, charcoal cartridge filters, silver zeolite cartridges, sodium hydroxide media, and silica gel cartridges

- Compilation of laboratory analyses with measured stack flow data or maximum stack flow rates to derive releases of radioactivity (i.e., curies) and average concentrations of radioactivity in sampled emissions

- Calculation of quantities of radionuclides released and average concentrations for a calendar year, for a specific discharge point, or a specific area within the Hanford Site

- Preparation of the reports identified in Section 2.1 for publication and release to the appropriate agencies and to the public. document.

The items listed above are outlined in succeeding sections of this

\subsection{APPLICABILITY TO WESTINGHOUSE HANFORD COMPANY QUALITY ASSURANCE PROGRAM}

This QAPJP is specific to those activities performed within the Effluent Monitoring (EM) group to collect and verify sample analysis data received, to combine these data with facility operations data, and to report the combined data. Where the analytical results are below minimum detectable concentrations, emissions are reported as non-detectable curies.

This QAPjP is prepared in compliance with the guidance in Interim Guidelines and Specifications for Preparing Quality Assurance Project Plans, QAMS-005/80 (EPA 1983) and "Quality Assurance Methods" 40 CFR 61, Appendix B, Method 114 (EPA 1989). The QAPjP describes the means selected to implement the overal1 quality assurance (QA) program requirements defined by the Quality Assurance Hanual, WHC-CM-4-2. The implementing procedures, plans, and instructions are appropriate for the control of radioactive airborne emissions data required by Method 114 and applicable DOE orders.

Distribution and control of this plan shall be in compliance with Qual ity Requirement (QR) 6.0, "Document Control," from WHC-CM-4-2. The QAPjP distribution shall routinely include all review/approval personnel indicated on the title page of the document and other individuals designated by EM. This QAPJP shalT be reviewed and updated at least annually or whenever changes are made to the program. 


\subsection{MINIMUM QUALITY ASSURANCE REQUIREMENTS}

The following quality assurance elements must be addressed as a minimum:

- Establishment of a sample tracking system for positive identification of samples and data through all the phases of the sample collection, analysis, and reporting system [CFR 61, Appendix B, Method 114, QA Methods 4.6 (EPA 1989)]

- Assignment of a unique samp7ing-point identification by electronic data processing (EDP) code by EM for use in analysis of site samples

- Establishment of required sample analyses and minimum detectable concentrations for specific radionuclides for radioactive airborne emissions and sample scheduling [QA Methods 4.3.4 (EPA 1989)]

- Identification of data quality objectives for the laboratory in the statement of work or contractual agreement [QA Methods 4.3.5 (EPA 1989)]

- Definition of reporting requirements for laboratories performing analyses

- Definition of data assessment procedures for evaluation of sample analyses and operations data

- Definition of requirements for reporting to EPA and DOE [QA Methods 4.9 (EPA 1989)]. 
WHC-EP-0528-2

This page intentionally left blank. 
WHC-EP-0528-2

\subsection{PROJECT ORGANIZATION AND RESPONSIBILITIES}

\subsection{PROJECT MANAGEMENT}

Within Westinghouse Hanford Company, the EM group has primary responsibility for preparing, for submission to EPA and DOE, all reports of radioactive airborne releases from record stacks and vents. The EM function has responsibility for approving implementation of requirements listed in the Environmental Compliance Manual, WHC-CM-7-5, for radioactive airborne emissions monitoring and sampling systems. Additional responsibilities include providing information on analytes of interest and required minimum detectable quantities, and conducting compliance assessments of radioactive airborne emissions sampling and monitoring equipment and records within the facilities co-operated by Westinghouse Hanford.

Responsibilities assigned for sampling, analyses, data compilation, reporting, and oversight are described below and shown in the organization matrix in Table 3-1 [QA Methods 4.1 (EPA 1989)].

\subsubsection{Effluent Monitoring}

Individuals designated by management within EM have responsibility for compiling and verifying sample analyses, compiling stack flow rates and operations data, performing final calculations, and reporting this information to DOE and EPA. In addition, EM engineers cognizant of specific facilities are responsible for reviewing and approving any record sampling systems planned for installation on stacks in facilities under their oversight, for performing compliance assessments of radioactive airborne emissions sampling and monitoring systems, and for investigating any increases in radionuclide emissions indicated by sample analysis results. The EM group reviews/approves sample schedules and sampling points, and provides technical requirements for radioactive air sample analysis including the list of specific radionuclides to be analyzed, and lower limits of detection for the laboratory. These activities are carried out by following the requirements set forth in the Environmental Compliance Manual (WHC-CM-7-5) and Effluent Monitoring Procedures (WHC-IP-1066) (WHC 1995C).

\subsubsection{Effluent Monitoring Data Management}

EM is responsible for compiling radioactive air sampling data and flow rates to be used in preparing regulatory reports. Additional responsibilities include verification of sample analysis parameters received from the laboratory and providing sampling schedules. EM assigns EDP codes for onsite laboratory analysis of stack/vent samples and establishes the analyses to be performed by that laboratory. In addition, the EM group provides the data quality objectives for the sampling analysis activities and compares sample analysis results with previous release information to establish trends in releases and identify required investigations of any anomalous data. These activities are carried out by following the requirements set forth by the procedures documented in the preceding paragraph. 
WHC-EP-0528-2

\subsubsection{Effluent Nonitoring Reporting}

EM is assigned the task of compiling radioactive airborne emissions release data into summary information for inclusion in the reports listed in Section 2.1 .

\subsection{SUPPORTING ORGANIZATIONS}

Technical and administrative support for compiling radioactive airborne emissions data is provided by the organizations described in the following paragraphs.

\subsubsection{Westinghouse Hanford Operational Health Physics Personnel}

Health Physics provides the sampling effort for the radionuclide air emissions under the technical direction of the facility cognizant engineer. The Automated Bar Coding of Air Samples at Hanford (ABCASH) system provides automated data acquisition and tracking of air filter sample information. The sampling collection, tracking, and handling procedures for the effluent samples are contained in WHC-EP-1066 (WHC 1995C). The Policies and Procedures group prepares the procedures for sample collection and for the sample tracking system used by the Health Physics organization.

The sampling activities should be done in accordance with the stack monitoring and sampling requirements of 40 CFR 61, Appendix B, Method 114 (EPA 1991). The QA activities included in Method 114 and performed by this group are described below.

- Section 4.3.4 describes the sample collection requirements.

- Section 4.6 covers the sample tracking system for positive identification of samples from sample collection to delivery to the laboratory, as. well as sample handling and preservation procedures to maintain the integrity of samples during collection and storage.

\subsubsection{Westinghouse Hanford Company Analytical and Environmental Quality Assurance}

The Analytical and Environmental Quality Assurance (AEQA) organization performs surveillances to verify activities described in Section 2.2. AEQA reviews and approves laboratory analytical procedures for quality assurance (QA)/quality control (QC) requirements, surveils EM and laboratory activities associated with radionuclide emissions stack monitoring, and performs laboratory reviews and audits.

\subsubsection{Westinghouse Hanford Compliance Assurance}

The Compliance Assurance (CA) personnel perform internal compliance assessments and appraisals of radioactive airborne emissions sample collection, analysis, and reporting for Westinghouse Hanford facilities. This group is committed to performing at least one compliance assessment/appraisal annually on air emissions activities. 


\subsubsection{Westinghouse Hanford Facility Cognizant Engineers}

These personnel receive, review, and transmit to EM the average stack flow data from measurements performed by Westinghouse Hanford Ventilation and Balance personne1. The facility cognizant engineers are responsible for monitoring emissions from stacks at their own facilities and for reviewing the analytical requirement letter of instruction, produced by $E M$, to the laboratory. The cognizant engineers are responsible for being aware of changes in emissions and submitting them for laboratory analysis so that the facility effluent monitoring plans can be kept current.

\subsubsection{Westinghouse Hanford Process Analytical Laboratory}

These personnel perform radiochemical analyses on radioactive airborne emissions sample media collected from stacks at Westinghouse Hanford facilities. The specific radionuclides to be analyzed for are determined by EM with the assistance of the facility cognizant engineer. Laboratory personnel responsibilities include the incorporation of their analytical data into the existing laboratory data files for timely electronic transmission to EM.

The laboratory shall have a QA plan and analytical procedures that meet the requirements of 40 CFR 61, Appendix B, Method 114 (EPA 1991). The QA activities identified in Method 114 and described in WHC-EP-0536-2,

Section 6.2.2 (WHC 1995a), must be addressed in Taboratory QA plans.

\subsubsection{Pacific Northwest National Laboratory Health Physics}

This organization is designated by DOE to perform dose modeling for the Hanford Site, including dose modeling for stacks co-operated by Westinghouse Hanford. Northwest Laboratory derives the EDE by using EPA-approved dose models [CAP-88 (Beres 1990)], in combination with the Hanford Site model [GENII (Napier et a7. 1988)] used to calculate the contribution of long-7ived daughter ingrowth. Data supplied by the Northwest Laboratory Health Physics organization are included in the annual report of airborne emissions prepared for EPA, and in the Northwest Laboratory environmental surveillance report prepared for DOE.

\subsubsection{Pacific Northwest National Laboratory, Laboratory Safety Department, Environmental Compliance Section}

These personnel are responsible for transmitting radioactive airborne emissions release data for Northwest Laboratory stacks to EM for inclusion in the EIS/ODIS report and the annual air emissions report. The data transfer is made electronically to the database used by EM for compiling all Hanford Site releases. These Northwest Laboratory personnel are also responsible for reviewing and updating annual emissions report narrative descriptions of all Northwest Laboratory stacks discharging radioactive emissions. 


\subsubsection{Pacific Northwest National Laboratory Chemistry and Analysis}

These personnel are located in the 300 Area laboratory operated for DOE by Northwest Laboratory. They analyze radioactive airborne emission samples taken from Westinghouse Hanford co-operated facilities in the 300 and 400 Areas. They receive stack flow measurement data from the 300/400 Area EM cognizant engineer and determine the concentrations using data computation software. Then they transmit the radiochemical analyses in written form to EM. Procedures used for analyzing stack samples are prepared within this organization and controlled by Northwest Laboratory internal controls.

\subsubsection{Northwest Laboratory - Analytical Laboratory Technical Administration (ALTA)}

These personnel provide Tiaison between the 100 Area EM cognizant engineer and the offsite laboratory designated by DOE to perform radiochemical analyses at the Hanford Site. Included in their duties is the negotiation of contracts with the designated laboratory, oversight of the laboratory's performance, and revisions to the statement of work, and billing for work performed.

\subsubsection{Bechtel Hanford Incoporated}

Thermo-Analytical Hanford (TMA) provides Radiological Control services for Bechtel Hanford Incorporated (BHI). TMA radiological control technicians perform air sampling activities for the radionuclide air emissions program under the technical direction of the facility cognizant engineer. The TMA Procedures group prepares and issues the procedures for air sample collection for those facilities under BHI management. 


\begin{tabular}{|c|c|c|c|c|c|}
\hline & ४ै+ & Approval & Performed & Review & Yaltdation \\
\hline 1 & $\begin{array}{l}\text { Provide analytical } \\
\text { criteria, and detection } \\
\text { limits, for radioanalyses } \\
\text { to onsite and offsite } \\
\text { laboratories }\end{array}$ & & EM & & \\
\hline 2 & $\begin{array}{l}\text { Sample schedules, statement } \\
\text { of work }\end{array}$ & & EM & AEQA & \\
\hline 3 & $\begin{array}{l}\text { Collect samples of } \\
\text { radioactive airborne } \\
\text { emissions from stacks and } \\
\text { record information on } \\
\text { sample envelope data }\end{array}$ & & HHC RC & & EM \\
\hline 4 & Analyze samples & EM & $\begin{array}{c}\text { LAB } \\
\text { QES } \\
\text { PNNL, CA }\end{array}$ & & \\
\hline 5 & Audit laboratory $Q A / Q C$ & & $\begin{array}{l}\text { AEQA, CA } \\
\text { PNNL-ALTA }\end{array}$ & & \\
\hline 6 & $\begin{array}{l}\text { Prepare radioactive } \\
\text { airborne emissions data } \\
\text { compilation and reporting } \\
\text { procedures }\end{array}$ & & $E M$ & AEQA & \\
\hline 8 & $\begin{array}{l}\text { Verify sample analyses and } \\
\text { stack flow rate data from } \\
\text { Vent and Balance/facility } \\
\text { cognizant engineers; } \\
\text { transmit data to EM }\end{array}$ & & & & EM* \\
\hline 9 & $\begin{array}{l}\text { Prepare annual } \\
\text { environmental surveillance } \\
\text { report for the Hanford Site }\end{array}$ & & PNNL LS & EM & \\
\hline 10 & $\begin{array}{l}\text { Compile sampling results, } \\
\text { flow data, and data on } \\
\text { duration of operation into } \\
\text { annual releases in curie } \\
\text { quantities and annual } \\
\text { average concentrations }\end{array}$ & & $\begin{array}{l}\text { EM } \\
\text { PNNL LS }\end{array}$ & & \\
\hline
\end{tabular}




\begin{tabular}{|c|c|c|c|c|c|}
\hline & ২) & Approvat & $\begin{array}{l}\text { Performed } \\
\text { ofy }\end{array}$ & Réviêt & Validation \\
\hline 11 & $\begin{array}{l}\text { Prepare EIS/ODIS report, } \\
\text { annual air emissions report } \\
\text { and annual effluent release } \\
\text { report for Hestinghouse } \\
\text { Hanford }\end{array}$ & & EM & $\begin{array}{l}\text { WHC OPS** } \\
\text { PNNL LS }\end{array}$ & \\
\hline 12 & $\begin{array}{l}\text { Compute annual effective } \\
\text { dose equivalent to } \\
\text { maximally exposed } \\
\text { individual for air pathway } \\
\text { from Hanford Site } \\
\text { operations }\end{array}$ & & $\begin{array}{l}\text { PNNL } \\
\text { HP**** }\end{array}$ & & \\
\hline 13 & $\begin{array}{l}\text { Conduct programmatic audits } \\
\text { of emissions data handling }\end{array}$ & & $\begin{array}{l}\text { CA and } \\
\text { AEQA }\end{array}$ & & \\
\hline 14 & $\begin{array}{l}\text { Conduct compliance } \\
\text { assessments on radiation } \\
\text { airborne sampling and } \\
\text { monitoring systems }\end{array}$ & & EM & & \\
\hline
\end{tabular}

\title{
Legend
}

\author{
CA: $\quad$ Compliance Assurance \\ EM: $\quad$ Effluent Monitoring \\ Lab: $\quad$ Onsite or offsite lab \\ QES: $\quad$ Quanterra Environmental Services \\ PNNL CA: Pacific Northwest National Laboratory Chemistry and Analysis \\ PNNL HP: Pacific Northwest National Laboratory Health Physics \\ PNNL LS: Pacific Northwest National Laboratory Safety \\ PNNL ALTA: Pacific Northwest Laboratory Analytical Laboratory Technical Administration \\ QA/QC: $\quad$ Quality Assurance/Quality Control \\ WHC RC: Hestinghouse Hanford Radiological Control \\ WHC OPS: Westinghouse Hanford Operations \\ AEQA: Analytical and Environmental Quality Assurance
}

* Sample analysis and stack flow rate data are verified/validated by Environmental Release Summary (ERS) anomalous reports.

** Westinghouse Hanford Operations reviews only the effluent report.

*** Review and approval by the Hanford Site Dose Overview Panel. 


\subsection{QUALITY ASSURANCE OBJECTIVES FOR MEASUREMENTS}

The QA objectives within the QAPjP for the measurements and controls applicable to radioactive airborne emissions data collection, verification, compilation, and reporting, are related to:

- Defining analytes of interest for the analytical laboratories from emission characterizations provided by the facility

[QA Methods 4.3.1 (EPA 1989)]

- Prescribing analytical detection limits and requiring precision and accuracy appropriate to the radioactive airborne emissions sample analyses for Westinghouse Hanford facilities at the Hanford Site [QA Hethods 4.4 (EPA 1989)]

- Defining data representativeness, completeness, and comparability [QA Methods 4.4.(EPA 1989)].

Completeness objectives for contractually and procedurally established requirements (i.e., precision, accuracy, timeliness, etc.) shali be met for $90 \%$ of the requested determinations. Corrective action measures using specified procedures shall be initiated by EM, AEQA, facility cognizant engineers, or laboratories as appropriate. A11 laboratory QA/QC requirements sha11 be identified in a contractual agreement (WHC-EP-0835) (WHC 1995b).

\subsection{ANALYTES OF INTEREST AND ANALYTICAL METHOD SELECTION}

A Tetter of instruction to the WSCF Laboratory, listing the required radioactive analytes from record sampling systems reported in calendar year air emission reports and the EIS/ODIS, is sent out on a fiscal year basis using the following minimum requirements (WHC-CM-3-5):

- Sampling systems shall be provided for all airborne effluents that have the potential to exceed $10 \%$ of the Derived Concentration Guide (DCG) - Public Value on an annual average, as these values are given in Figure III-1 of DOE Order 5400.5, Radiation Protection of the Public and the Environment (DOE 1990).

- DOE facilities shall not cause an EDE greater than 10 millirem per

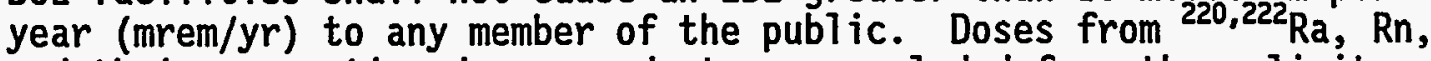
and their respective decay products are excluded from these limits.

- A quality record shall be provided of emissions from any point of release that, if unfiltered, could present a maximum offsite exposure of $0.1 \mathrm{mrem} / \mathrm{yr}$ EDE.

- Where the ratio of radioisotopes present in the emissions is unknown or changing, the isotope present with the most restrictive DCG shall be assumed for gross beta/gamma and gross alpha activity. 
- Additional specific radionuclide analyses shall be performed on certain stacks/vents (daily, weekly, biweekly, or monthly) as deemed appropriate by EM, based on historical data.

\subsection{REPRESENTATIVENESS, COMPLETENESS, AND COMPARABILITY}

Goals for data representativeness, completeness, and comparability are addressed qualitatively by specification of discharge points and sampling intervals per WHC-CM-7-5. The total measurement error for analytical data, excluding errors caused by facility stream volume measurement, shall be computed at the $95 \%$ confidence level. . The limit of detection by the laboratory shall be equal to or 1ess than 10\% of the DCG (WHC-CM-7-5). Proposed technical solutions shall be provided to EM by the laboratory for any radionuclide measurement that does not meet the required limit of detection. Goals for data representativeness, completeness, and comparability, specific to the laboratory performing the sample analyses, are addressed within WHC-EP-0835 (WHC 1995b), prepared by EM for the WSCF laboratory.

Failure to meet criteria 7 isted in WHC-CM-7-5 and the contractual documentation shal1 be documented in data summary reports and shall be considered during the data verification. Corrective action measures shall be initiated, documented, and reported by the laboratories, as appropriate [QA Methods 4.3.2 (EPA 1989)]. 
Table 4-1. Radionuclides Requiring Routine Analyses.

\begin{tabular}{|c|c|c|c|}
\hline Radto & 100 & 200 hrea & $\begin{array}{l}3007400 \\
\text { ard }\end{array}$ \\
\hline Gross alpha & $x$ & $x$ & $x$ \\
\hline Gross bete & $x$ & $x$ & $x$ \\
\hline${ }^{3} \mathrm{H}$ & & $x$ & $x$ \\
\hline${ }^{\infty} \mathrm{CO}$ & $x$ & & \\
\hline${ }^{\infty} \mathrm{Sr}$ & $x$ & $x$ & \\
\hline${ }^{106} \mathrm{RU}$ & & $x$ & \\
\hline${ }^{113} \mathrm{Sn}$ & & $x$ & \\
\hline${ }^{125} \mathrm{Sb}$ & & $x$ & \\
\hline 2291 & & $x$ & \\
\hline${ }^{137} \mathrm{Cs}$ & $x$ & $x$ & \\
\hline${ }^{154} \mathrm{EU}$ & $x$ & & \\
\hline $23 x \mathrm{U}$ & & $x$ & $x$ \\
\hline $25 y$ & & $x$ & $x$ \\
\hline $2 x y$ & & $x$ & \\
\hline $209 y$ & & $x$ & $x$ \\
\hline${ }^{230} \mathrm{Pu}$ & $x$ & $x$ & \\
\hline $299.240 \mathrm{Pu}$ & $\bar{x}$ & $x$ & \\
\hline Gross u & & $x$ & \\
\hline${ }^{241} \mathrm{Am}$ & $x$ & $x$ & \\
\hline
\end{tabular}

* Values calculated based on rate of Ar production related to power levels at the Fast flux Test Facility. 


\section{WHC-EP-0528-2}

This page intentionally left blank. 
WHC-EP-0528-2

\subsection{SAMPLING PROCEDURES}

\subsection{SAMPLING PROCEDURES}

Radioactive airborne emission sample collection activities are conducted by Radiation Control technicians performing sampling of Westinghouse Hanford co-operated facilities, in accordance with WHC-IP-0718, Health Physics Procedures (WHC 1993). Facility operations personnel are responsible for procuring, installing, and maintaining sampling systems, per the requirements of $\mathrm{HHC}-\mathrm{CM}-7-5$, and for preparing and approving work control documentation provided to Ventilation and Balance personnel measuring average stack flow rates of 200,300 , and 400 Areas stacks/vents. Administrative controls, to ensure prompt response in the event that emission levels increase because of unplanned operations, are contained in $\mathrm{HHC}-\mathrm{CM}-7-5$, Environmental Compliance Manual [QA Methods 4.2 (EPA 1989)].

Radioactive airborne emission sample collection activities for those facilities under management by Bechtel Hanford Incorporated are performed by Thermo-Analytical Hanford radiological control technicians in accordance with $\mathrm{BHI}-\mathrm{SH}-04$, Radiological Control Work Instructions (BHI 1995).

\subsection{SUPPORTING PROCEDURES}

Procedures in place for performance of radioactive airborne emissions sample handling, data collection, verification, compilation, calculation, and reporting by EM, are included in WHC-IP-1066 (WHC 1995C). Procedures specific to analyses performed by the 325 Laboratory are contained in PNL-MA-597, Vols. 6 and 7, Analytical Chemistry Laboratory Manual (PNL 1991).

\subsection{PROCEDURE APPROVALS AND CONTROL}

The latest approved versions of the procedures listed shall apply in a11 cases. All procedures are available for regulatory review on request.

\subsection{PROCEDURE ADDITIONS AND CHANGES}

New procedures or revisions to existing procedures shall be developed in accordance with Management Requirements and Procedures, (MRP) 2.16, $W H C-C M-1-3$, and QR 5.0, and 6.0, WHC-CM-4-2.

\subsection{SAMPLING SCHEDULE}

Record sampling is used as the basis for reporting radioactive airborne emissions to DOE and EPA. As used in this QAPJP, a record sample is a representative sample collected in a sample system for laboratory analysis. Record sampling schedules are reviewed and approved by EM for a 11 Hestinghouse Hanford facilities. Any changes in radioactive gaseous emissions record sampling schedules, including temporary or one-time deviations, shall be preapproved by EM, as specified in $\mathrm{HHC}-\mathrm{CM}-7-5$. 
Facility-specific sampling schedules are included in the procedures created for emissions data management and reporting. Sampling schedules and locations for facilities in the 100,200,300, 400, and 1100 areas are shown in WHC-IP-1066 (WHC 1995C). Changes in sampling schedules or locations are incorporated into this document during periodic reviews of the procedure under internal schedules established by EM management.

\subsection{SAMPLING SYSTEM DESIGN}

Record sampling system designs are reviewed and approved by EM and AEQA in accordance with the requirements found in WHC-CM-7-5 and 40 CFR 61, Subpart H (EPA 1989). 
Table 5-1. Supporting Procedures for Radioactive Airborne Emissions Sample Collection, Data Compilation, Calculation and Reporting. (4 sheets)

\begin{tabular}{|c|c|c|c|}
\hline Procedure & Procedure & ใै. & +. Faclity \\
\hline \multirow[t]{6}{*}{$\begin{array}{l}\text { Sample } \\
\text { collection }\end{array}$} & $\begin{array}{l}\text { WHC-IP-0718 } \\
\text { (WHC 1993) } \\
\text { Section } 3.3 .1\end{array}$ & Air Sampling & \multirow{3}{*}{$\begin{array}{l}\text { A11 } \\
\text { Westinghouse } \\
\text { Hanford stacks } \\
(100,200,300, \\
400 \text { Areas) }\end{array}$} \\
\hline & Section 3.3.2 & $\begin{array}{l}\text { Gaseous Effluent Monitoring } \\
\text { System Inspection and Sample } \\
\text { Exchange }\end{array}$ & \\
\hline & Section 3.3 .3 & $\begin{array}{l}\text { Automated Bar Coding of Air } \\
\text { Samples at Hanford (ABCASH) }\end{array}$ & \\
\hline & $\begin{array}{l}\text { Occupational } \\
\text { Health and } \\
\text { Safety } \\
\text { Scheduled } \\
\text { Radiation } \\
\text { Survey And } \\
\text { Task } \\
\text { Description } \\
\text { T-W-01 } \\
\text { (WHC 1992a) }\end{array}$ & $\begin{array}{l}\text { Scheduled Radiation Survey and } \\
\text { Task Description for T Plant }\end{array}$ & $\begin{array}{l}200 \text { Area, } T \\
\text { Plant }\end{array}$ \\
\hline & $\begin{array}{l}\text { Occupational } \\
\text { Health and } \\
\text { Safety } \\
\text { Scheduled } \\
\text { Radiation } \\
\text { Survey and } \\
\text { Task } \\
\text { Description } \\
\text { Task } \\
\text { No. J-W005 } \\
\text { Survey } \\
\text { No. 911562 } \\
\text { (Attachment A) } \\
\text { (WHC 1992b) }\end{array}$ & $\begin{array}{l}\text { Task Description for } 340 \text { Waste } \\
\text { Handling }\end{array}$ & $\begin{array}{l}300 \text { Area, } 340 \\
\text { Waste Handling } \\
\text { Facility }\end{array}$ \\
\hline & $\begin{array}{l}\text { BHI-SH-04 } \\
\text { Procedure } 7.9\end{array}$ & Effluent Monitors Inspection & $\begin{array}{l}\text { A11 BHI Stacks } \\
(100,200 \\
\text { Areas })\end{array}$ \\
\hline
\end{tabular}


Table 5-1. Supporting Procedures for Radioactive Airborne Emissions Sample Collection, Data Compilation, Calculation and Reporting. (4 sheets)

\begin{tabular}{|c|c|c|c|}
\hline Procedure: & ? 2 Procedure & (: & ractitty \\
\hline \multirow[t]{4}{*}{$\begin{array}{l}\text { Sampling } \\
\text { System } \\
\text { Operability } \\
\text { Checks }\end{array}$} & $\begin{array}{l}\text { WHC-IP-0718 } \\
\text { Section } \\
4.5 \mathrm{C}\end{array}$ & $\begin{array}{l}\text { Operation of the } 400 \text { Area } \\
\text { Effluent Monitoring System }\end{array}$ & $\begin{array}{l}\text { A11 } 400 \text { Area } \\
\text { gaseous } \\
\text { emission } \\
\text { sampling } \\
\text { systems }\end{array}$ \\
\hline & $4.6 C$ & $\begin{array}{l}\text { Operation of Tri-Carb Liquid } \\
\text { Scintillation Counter }\end{array}$ & $\begin{array}{l}\text { A11 } \\
\text { West inghouse } \\
\text { Hanford Stacks } \\
(100,200, \\
300,400 \\
\text { Areas) }\end{array}$ \\
\hline & $T-W-01$ & $\begin{array}{l}\text { Scheduled Radiation Survey and } \\
\text { Task Description for T Plant }\end{array}$ & $\mathrm{T}$ Plant \\
\hline & $\begin{array}{l}\text { BHI-SH-04 } \\
\text { Procedure } 7.9\end{array}$ & Effluent Monitors Inspection & $\begin{array}{l}\text { All BHI Stacks } \\
(100,200 \\
\text { Areas) }\end{array}$ \\
\hline \multirow[t]{2}{*}{$\begin{array}{l}\text { Sample } \\
\text { Shipment }\end{array}$} & $\begin{array}{l}\text { WHC-IP-0718 } \\
\text { Section } 3.2 .1\end{array}$ & $\begin{array}{l}\text { Radioactive Material Shipment } \\
\text { and Receipt Surveys }\end{array}$ & \multirow[t]{2}{*}{$\begin{array}{l}\text { Al1 radio- } \\
\text { active } \\
\text { airborne } \\
\text { samples }\end{array}$} \\
\hline & $\begin{array}{l}\text { WHC-IP-0718 } \\
\text { Section 3.1.1 }\end{array}$ & Material Release Surveys & \\
\hline \multirow[t]{7}{*}{$\begin{array}{l}\text { Sample } \\
\text { Analysis }\end{array}$} & LA-508-002 & $\begin{array}{l}\text { Detection Levels for } \\
\text { Radio-isotopic Counting }\end{array}$ & \multirow[t]{7}{*}{$\begin{array}{l}\text { WSCF } \\
\text { Laboratory }\end{array}$} \\
\hline & LA-508-110 & $\begin{array}{l}\text { Operation of the Tennelec } \\
\text { LB-5500 Alpha/Beta Counting } \\
\text { System }\end{array}$ & \\
\hline & LA-508-051 & $\begin{array}{l}\text { Alpha Energy Analysis on the } \\
\text { Canberra Jupiter }{ }^{2} \text { System }\end{array}$ & \\
\hline & LA-549-412 & $\begin{array}{l}\text { Dissolution of Versapor }{ }^{3} \text { Type } \\
\text { Filters - WSCF }\end{array}$ & \\
\hline & LA-220-406 & $\begin{array}{l}\text { Strontium- } 89 \text { and } 90 \text { in Aqueous } \\
\text { samples by SR-Spec Separation }\end{array}$ & \\
\hline & LA-542-401 & $\begin{array}{l}\text { Electrodeposition of Actinides } \\
\text { - WSCF }\end{array}$ & \\
\hline & LA-218-412 & $\begin{array}{l}\text { Tritium Analysis on Silica Gel } \\
\text { by Liquid Scintillation } \\
\text { Counting }\end{array}$ & \\
\hline
\end{tabular}


Table 5-1. Supporting Procedures for Radioactive Airborne Emissions Sample Collection, Data Compilation, Calculation and Reporting. (4 sheets)

\begin{tabular}{|c|c|c|c|}
\hline Procedure & Procedure & 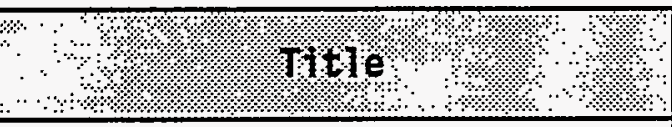 & Facility \\
\hline \multirow[t]{13}{*}{$\begin{array}{l}\text { Sample } \\
\text { Analysis } \\
\text { (cont'd) }\end{array}$} & LA-220-407 & $\begin{array}{l}\text { Measurement of Self-Absorption } \\
\text { of Beta Radiation for } 90 \mathrm{SR} \\
\text { determinations }\end{array}$ & \multirow[t]{13}{*}{$\begin{array}{l}\text { HSCF } \\
\text { Laboratory } \\
\text { (cont'd) }\end{array}$} \\
\hline & LA-508-471 & $\begin{array}{l}\text { Alpha Energy Data Acquisition } \\
\text { and System Checkout Using Alpha } \\
\text { Management Software on the } \\
\text { Genie }^{4} \text { System }\end{array}$ & \\
\hline & LA-508-472 & $\begin{array}{l}\text { Alpha Energy Sample Processing } \\
\text { Using Alpha Management software } \\
\text { on the Genie System }\end{array}$ & \\
\hline & LA-508-481 & $\begin{array}{l}\text { Gamma Energy Analysis Using } \\
\text { PROcount }{ }^{5} \text { Software }\end{array}$ & \\
\hline & LA-508-415 & $\begin{array}{l}\text { Operation of the PROtean } \\
\text { 2-Inch Alpha/Beta Counting } \\
\text { System }\end{array}$ & \\
\hline & LA-508-421 & $\begin{array}{l}\text { Operation of the Tri-Carb } \\
\text { Mode } 72500 \text { TR Liquid } \\
\text { Scintillation }\end{array}$ & \\
\hline & LA-508-110 & $\begin{array}{l}\text { Operation of the Tennelec } \\
\text { LB-5500 Alpha/Beta Counting } \\
\text { System }\end{array}$ & \\
\hline & LA-542-401 & $\begin{array}{l}\text { Electrodeposition of Actinides } \\
\text { - WSCF }\end{array}$ & \\
\hline & LA-548-411 & $\begin{array}{l}\text { Preparation of Mounts for } \\
\text { Liquid Scintillation Counting - } \\
\text { HSCF }\end{array}$ & \\
\hline & LA-548-421 & $\begin{array}{l}\text { Preparation of Sample Mounts } \\
\text { for Gamma Energy Analyses }\end{array}$ & \\
\hline & LA-548-442 & $\begin{array}{l}\text { Preparation of Quarterly Filter } \\
\text { Composites for Gamma Analyses }\end{array}$ & \\
\hline & LA-925-407 & $\begin{array}{l}\text { Uranium by Laser Induced } \\
\text { Kinetic Phosphorescence }\end{array}$ & \\
\hline & LA-943-424 & $\begin{array}{l}\text { Americium and PTutonium } \\
\text { TRU-SPEC Separation and } \\
\text { Neodymium Fluoride } \\
\text { Precipitation Plating }\end{array}$ & \\
\hline
\end{tabular}


Table 5-1. Supporting Procedures for Radioactive Airborne Emissions Sample Collection, Data Compilation, Calculation and Reporting. (4 sheets)

\begin{tabular}{|c|c|c|c|}
\hline Procedure & Procedure & ( & Factitty? \\
\hline \multirow[t]{6}{*}{$\begin{array}{l}\text { Sample } \\
\text { Analysis } \\
\text { (cont'd) }\end{array}$} & LO-150-133 & $\begin{array}{l}\text { Processing Record Stack and } \\
\text { Red-Bordered (Emergency) Air } \\
\text { Samples }\end{array}$ & \multirow[t]{6}{*}{$\begin{array}{l}\text { WSCF } \\
\text { Laboratory } \\
\text { (cont'd) }\end{array}$} \\
\hline & LO- $150-415$ & $\begin{array}{l}\text { Instrument Standards Counting } \\
\text { Schedule - WSCF Nuclear } \\
\text { Spectroscopy and Air Sample } \\
\text { Laboratories }\end{array}$ & \\
\hline & LQ-508-002 & $\begin{array}{l}\text { Calibration Guidelines for } \\
\text { Window-Type Gas Flow Alpha/Beta } \\
\text { Proportional Counters }\end{array}$ & \\
\hline & $L Q-508-005$ & $\begin{array}{l}\text { Calibration of Beta Detectors } \\
\text { for SR } 90\end{array}$ & \\
\hline & $L Q-508-405$ & $\begin{array}{l}\text { Gamma Energy Analyzer System } \\
\text { Calibration Using Procount } \\
\text { Software }\end{array}$ & \\
\hline & $\mathrm{HHC}-\mathrm{CM}-5-4$ & $\begin{array}{l}\text { Analytical Chemistry Services } \\
\text { Laboratories - Operating } \\
\text { Instructions }\end{array}$ & \\
\hline $\begin{array}{l}\text { Data } \\
\text { Handling } \\
\text { and } \\
\text { Reporting }\end{array}$ & $\begin{array}{l}\text { WHC-IP-1066 } \\
(\text { WHC 1995C) }\end{array}$ & Effluent Monitoring Procedures & $\begin{array}{l}\text { Al1 } \\
\text { Westinghouse } \\
\text { Hanford } \\
\text { facilities }\end{array}$ \\
\hline
\end{tabular}

\footnotetext{
${ }^{1} \mathrm{LA}, \mathrm{LO}$ and LQ procedures are 7 isted numerically in Section 17.0.

2Trademark of Canberra Industries, Inc., Meridian, Connecticut

${ }^{3}$ Trademark of Gelman Sciences, Ann Arbor, Michigan

${ }^{4}$ Trademark of Canberra Industries, Inc., Meridian, Connecticut

${ }^{5}$ Trademark of Canberra Industries, Inc., Meridian, Connecticut

Trademark of PROtean, Inc., Oak Ridge, Tennessee

${ }^{7}$ Trademark of Packard Instrument Company (Canberra Industries, Inc., Meridian, Connecticut

${ }^{8}$ Trademark of Eichrom Industries, Inc., Darien, Illinois
} 


\subsection{SAMPLE CUSTODY}

During the collection process, all radioactive airborne emissions samples are subject to the controls identified in WHC-IP-0718, Health Physics Procedures (WHC 1993), the facility chain of custody procedure, and those procedures 1isted in Table 5-1. Sample labels or envelopes are used to record information on sample location, time on and off, flow rate, rotameter, vacuum, EDP code, and signature of sample taker, as described in WHC-IP-1066 (WHC 1995c). For those samples sent to the 200 Area process analytical laboratory, radioactive emissions sample receipt, storage, analyses, and disposal are governed by procedures in place at the laboratory described in the Taboratory's quality assurance program documentation. For those samples sent to 300 Area and offsite laboratories for radioanalyses, sample chain-of-custody procedures are required by contractual documentation.

Tracking of radioactive airborne emissions sample handling and analyses is controlled by EM through assignment of unique EDP codes for each sample location. These unique EDP codes are used by the analytical laboratories to report their results to EM (see Section 3.1). For 300 and 400 Area samples, tracking is controlled through the use of EIS/ODIS alpha-numeric identifiers that are assigned to sampling locations and by which analyses are reported. For the 100 area, samples are tracked through a chain-of-custody log book maintained by facility operations. Each radioactive effluent sample is assigned a unique sample identification number prior to shipment to the offsite Taboratory for analysis [QA Methods 4.6 (EPA 1989)]. A unique sample number is also assigned to composite air samples, and the individual samples making up the composite are identified. 
WHC-EP-0528-2

This page intentionally left blank. 
WHC-EP-0528-2

\subsection{CALIBRATION PROCEDURES}

Activities conducted in support of radioactive airborne emissions data compilation and reporting do not require equipment calibration [QA Methods 4.3 .6 (EPA 1989)]. 
WHC-EP-0528-2

This page intentionally left blank. 


\subsection{ANALYTICAL PROCEDURES}

Analytical procedures performed by laboratories used for airborne radioactive emissions analyses are outside the scope of this QAPJP. Per the regulations, analytical methods or procedures based on reference methods identified in 40 CFR 61, Appendix B, Method 114 (EPA 1991), shal1 be used or alternate methods developed and approved before use for all analyses required for NESHAP compliance. 
WHC-EP-0528-2

This page intentionally left blank. 


\subsection{MONITORING AND REPORTING CRITERIA}

Criteria for radioactive airborne emissions sampling and monitoring are identified in the Environmental Compliance Manual, WHC-CM-7-5. Annual emissions are reported to EPA in compliance with 40 CFR 61, Subpart H, Section 61.94, "Reporting" (EPA 1989). Additional requirements are identified in WHC-CM-7-5, such as: determining radionuclide emissions; describing radioactive materials used at the Hanford Site; listing stacks, vents, or other points where radioactive materials are released to the ambient air; supplying all user-supplied input parameters for the computer dose calculation models and the source of these data; and reporting compliance with the standard that emissions from the Hanford Site not exceed those amounts that would cause any member of the public to receive in any year an effective dose equivalent (EDE) of $10 \mathrm{mrem} / \mathrm{yr}$.

Annual reports showing the Hanford Site contribution to the EIS/ODIS report are prepared in compliance with DOE Order 5400.1, Chapter II, "Notification and Reports," Item 5, "Reports on Radioactive Effluent/Onsite Discharge/Unplanned Releases" (DOE 1988). Information is sent to the EIS/ODIS database by direct electronic data transfer from the Effluent Monitoring group.

Information compiled for the EIS/ODIS report of radioactive airborne emissions is then included in the annual environmental release report for the Hanford Site prepared annually by Northwest Laboratory in compliance with DOE Order 5400.1, Chapter II, "Notification and Reports, " Item 4, "Annual Site Environmental Report" (DOE 1988). This report, which is prepared for transmittal to DOE headquarters, includes data on emissions from discharge points on the Hanford Site and the resultant EDE.

Annual summaries of radioactive airborne emissions, organized by area and discharge point, are also included in the annual report of environmental emissions prepared for Westinghouse Hanford facilities. This report is prepared in accordance with the reporting requirements in DOE Order 5400.1 (DOE 1988). Hestinghouse Hanford publishes the report to provide the DOE Richland Field Office with detailed information on the types of releases to the environment that occur from operation of specific Hanford Site facilities. EM has been delegated the responsibility for compiling all of the reports described above. 
WHC-EP-0528-2

This page intentionally left blank. 
WHC-EP-0528-2

\subsection{DATA REDUCTION, VERIFICATION AND REPORTING}

Within this QAPJP, data reduction, verification, and reporting of radioactive airborne emissions is performed by the EM as described in Section 3.0.

\subsection{DATA REDUCTION}

To compile radioactive airborne emissions for inclusion in the annual report prepared in compliance with 40 CFR 61, Subpart H (EPA 1989), EM receives sample analyses from a laboratory designated to perform analyses. The analyses are combined with measured average stack flow rates and sample and stack operation data to determine average annual concentrations and activities (i.e., curies) of radionuclides released. This is accomplished by the Environmental Release Summary (ERS) database system owned and operated by EM.

Sample analysis data are received in various forms. The 100 Area EM cognizant engineer receives a written report and a computer disk or diskette containing the report from the offsite laboratory designated to perform the analyses. Sample analysis results are usually received in units of picocuries ( $\mathrm{pC} i$ ) per sample. In the 200 Area, EM receives total alpha and total beta sample analyses via electronic transmission and/or written report from the 200 Area laboratory in units of microcuries per sample ( $\mu \mathrm{Ci} / \mathrm{sample})$, ${ }^{212} \mathrm{~Pb}$ analyses in $\mu \mathrm{Ci}$ per milliliter, volatile isotopes in $\mathrm{PCi} / \mathrm{sample}$, uranium in grams per sample, and other specific radionuclide analyses in Pci/sample. The 300/400 Area EM cognizant engineer receives total alpha and beta and radioiodine concentrations from the 300 Area Taboratory in $\mu \mathrm{Ci}$ per cubic centimeter $\left(\mu \mathrm{Ci} / \mathrm{cm}^{3}\right)$ and total releases in $\mathrm{Ci}$ per run and enters that data manually on a particulate filter sample summary logsheet for use in computing annual releases, per instructions given in WHC-IP-1066 (WHC 1995C).

EM incorporates stack flow rates, stack and sample operation data, and sample analyses into the ERS system to derive average annual concentrations (stack volumes) and total releases. In the 100 Area, vent/stack flow data are derived from supporting documents and/or safety analysis reports. The formulas and methods for compiling data for Bechtel Hanford Incorporated and Westinghouse Hanford Company are included in WHC-IP-1066, Effluent Monitoring Procedures (WHC 1995C).

\subsection{DATA VERIFICATION}

Data compilation within EM includes only those activities necessary to verify that sample analyses, stack flow rates, and sampling and operation times are accurate against contractual agreements, EPA regulations, and DOE orders. EM is responsible for reviewing information received from contributing organizations and for resolving all anomalous data before reporting.

In the 100 Area, the results received from the contract lab or facility operations are reviewed by the cognizant EM person. The completeness of the data and compliance to the statement of work (if applicable) will be reviewed. 
WHC-EP-0528-2

The sample location and Westinghouse Hanford sample number reported by the contract lab will be verified with the sample tracking database entries. Any discrepancies between the database and laboratory report will be investigated by comparison with the sample logbook, chain-of-custody report, and radioactive shipment record per HHC-IP-1066, Section 8.4, "Data Validation and Verification Requirements" (WHC 1995c). . If the discrepancy cannot be resolved and the location or sample number positively identified, the results can be discarded as long as a record is kept of the reason for not verifying the results.

In the 200 Area, the cognizant EM person is responsible for reviewing the completed laboratory analyses. If any anomalous data appear, a more extensive review is made. This review would then include the comparison of sample envelope parameters versus the laboratory input of the sample and the comparison of present measured stack flows with past flow measurements. Instructions are given in WHC-IP-1066, Appendix A, "Radionuclide Air Emission Quantification and Data Handling" (WHC 1995c) to resolve anomalous conditions. Stack flow measurement data are entered by the facility cognizant engineer into ABCASH. Any significant changes in the stack flow measurements data is investigated by $E M$ in conjunction with the facility cognizant engineer. Anomalies data or outliners that indicate increased emissions in the absence of process changes are investigated by verbal and written requests made to the laboratory and to the cognizant facility personnel for an operations review. Sample analysis data verified as missing because of sample loss or collection failure is interpolated by the electronic database or EM by averaging the results of the sample analyses for the week previous and the week following the lost sample.

Data anomalies identified by Pacific Northwest National Laboratory Chemistry and Analysis in the 300/400 Area Stack Monitoring Analytical Report are resolved per the instructions given in WHC-IP-1066, Subsection 6.1.2.2, "Missing or Anomalous Data" (WHC 1995c). If the data are missing, Health Physics is contacted to provide the missing data. If the TIME ON does not agree with the TIME OFF of the preceding week's sample, the preceding weeks sample TIME OFF is used. Discrepancies in sample flow rate are resolved by contacting Health Physics to verify data. In all cases, the Northwest Laboratory Stack Monitoring Analytical Report reflects the corrected data.

\subsection{DATA REPORTING}

EM is responsible for preparing the reports shown in Section 2.1. Preparation of the reports is described in the following paragraphs.

\subsubsection{Effluent Information System/Onsite Discharge Information System Report}

For the EIS/ODIS report, EM compiles the total curies released and the total emissions volume for every discharge stack or vent included in the EIS/ODIS for the Hanford Site and transmits the information via direct electronic file transfer to the Idaho National Engineering Laboratory (INEL), Idaho Falls, Idaho. These data, sent electronically by April 1st each year, represent releases from the previous calendar year. They are downloaded into the Effluent Information System/On-Site Discharge Information System (EIS/ODIS) database, managed by INEL for the U.S. Department of Energy. 


\subsubsection{Hanford Site Environmental Report}

For the Hanford Site Environmental Report prepared by Northwest Laboratory, EM combines the EIS/ODIS emissions data for Westinghouse Hanford stacks and vents by area and specific radionuclide. The emissions data are incorporated into the text of the portion of the report prepared by Westinghouse Hanford and the text and data are then transmitted to Northwest Laboratory. The Northwest Laboratory Health Physics organization combines the emissions data with the Northwest Laboratory stack data to calculate offsite dose to the maximally exposed individual (MEI) for inclusion in the report.

\subsubsection{Air Emissions Report}

For the annual air emissions report required by 40 CFR 61 , Subpart $H$ (EPA 1989), EM compiles radioactive airborne emissions by area, radionuclide, and stack/vent. The offsite dose is provided by Northwest Laboratory Health Physics for the air pathway. This information is included in the report, which is compiled in conformance with directions given in 40 CFR 61, Subpart H, Section 61.94 .

\subsubsection{Environmental Release Report}

For the annual environmental release report, EM compiles average annual concentrations, total curies released, and total stack volumes for all Westinghouse Hanford stacks and vents. This information is incorporated, along with information about nonradioactive airborne emissions, into the section of the environmental release report that addresses the airborne releases. 
WHC-EP-0528-2

This page intentionally left blank. 


\subsection{INTERNAL QUALITY CONTROL}

EM prepares statements of work for onsite laboratories. For radioactive airborne emissions samples analyzed by the onsite laboratories, the following requirements are stipulated by contract:

- The laboratory shall ensure the integrity and validity of analytical test results through implementation of an internal QC program that includes written procedures and a corrective action system for discrepant results. This internal QC program should address data reduction, verification, and reporting at the laboratory. Any QA procedures for software used in data analysis should also be addressed by this program.

- The Taboratory shall prepare and analyze spiked, blank, and replicate samples to verify the accuracy and precision of all analytical results.

- Precision and accuracy data shall be obtained from analysis of quality control samples to demonstrate conformity with QC requirements.

- The contract laboratory shall provide reports on precision and accuracy. The contract laboratory shall also provide reports on participation in the EPA Environmental Radioactivity Laboratory Intercomparison Studies Program and the DOE Quality Assessment Program laboratory intercomparisons.

Quality control (QC) test results and laboratory intercomparison scores shall be provided quarterly. The QC tests shall be for accuracy, precision, completeness and background. Test results should be presented in bar-line graph style. All tests shall be in accordance with applicable requirements and procedures contained in the references listed in Section 1.0 of HHC-EP-0835 (HHC 1995b). Precision and accuracy are also described in Appendix G of WHC-EP-0536-2 (WHC 1995C). Some program requirements for the 325 Laboratory are described in Appendix H of WHC-EP-0536-2 (WHC 1995C).

Near Field Monitoring duplicates effluent and environmental samples for analysis. The WSCF Laboratory does not know the identity of these samples when it analyzes them.

The minimum detectable levels or concentrations for the radionuclides analyzed shall be identified in the laboratory contractual agreement for each facility [QA Methods 4.5 (EPA 1989)]. 
WHC-EP-0528-2

This page intentionally left blank. 


\subsection{PERFORMANCE AND SYSTEM AUDITS}

The EM group performs compliance assessments of radioactive airborne emissions systems, per WHC-CM-7-5, which are not classified as audits. The audit program administration within QC sha11 perform audits on the overa11 program activities identified in the QAPP. The Analytical and Environmental Quality Assurance is responsible for surveillance of activities associated with control of laboratory analysis (WHC-EP-0536-2) (WHC 1995a). This includes surveillance of the following activities:

- Reviewing and approving laboratory analytical procedures for QA/Quality control (QC) requirements

- Surveillance of Taboratory activities associated with the radionuclide emissions stack monitoring

- Participating as a $Q A / Q C$ specialist in laboratory reviews and audits. 
WHC-EP-0528-2

This page intentionally left blank. 


\subsection{DATA ASSESSNENT PROCEDURES}

Data assessment procedures used for radioactive airborne emissions sample analyses are under the control of the laboratory performing the analyses. EM reviews assessment information for trends, anomalies, etc. to verify contractual requirements. For 100 Areas analyses, the Northwest Laboratory technical liaison reviews the data assessment documentation provided by the offsite laboratory (see Section 4.2). 
WHC-EP-0528-2

This page intentionally left blank. 


\subsection{CORRECTIVE ACTION}

Corrective action requests required as a result of surveillance or audit activity shall be documented and dispositioned as required by WHC-CM-4-2, QR 15.0, "Control of Nonconforming Items;" Qual ity Instruction (QI) 15.1, "Nonconforming Item Reporting;" and/or QR 16.0, "Corrective Action." 
WHC-EP-0528-2

This page intentionally left blank.

14-2 


\subsection{QUALITY ASSURANCE REPORTS}

Radionuclide effluent monitoring shall be regularly assessed by compliance assessments, surveillance and auditing processes. Surveillance, nonconformance, audit and corrective action documentation shall be considered $Q A$ records and shall be documented and dispositioned as stated in WHC-EP-0536-2, Section 4.0, "Document Control and Records" (WHC 1995a). Compliance assessments of radioactive emissions sampling and monitoring systems are performed for Westinghouse Hanford facilities by EM. Compliance assessments are performed on a scheduled basis based on past history, need, staffing levels, and new regulatory requirements. Performance against the schedule may be affected by staffing levels. Compliance assessment checklists are not considered $Q A$ records. 
WHC-EP-0528-2

This page intentionally left blank.

$15-2$ 
WHC-EP-0528-2

\subsection{GLOSSARY}

\section{DEFINITIONS OF TERMS}

Accuracy. The measure of bias in a system. Sampling accuracy is normally assessed by evaluating matrix spiked samples and reference samples.

Activity. The nuclear transformations that occur as a radioactive materia1 decays.

Audit. Systematic checks to verify the quality of operation of one or more elements of the total measurement system. In this sense, audits may be either of two types: (1) performance audits, in which quantitative data are independently obtained for comparison with data routinely obtained in a measurement system; or (2) system audits, involving a qualitative onsite evaluation of laboratories or other organizational elements of the measurement system for compliance with established QA program and procedure requirements. For effluent monitoring at the Hanford Site, performance audit requirements are fulfilled by periodic submittal of blind samples to the primary laboratory, or the analysis of split samples by an independent laboratory. System audit requirements are implemented through the use of standard surveillance procedures.

Background. The normal or natural condition in an environmental parameter that is used to compare results from analyses of environmental samples.

Batch Sample. A single sample removed from a stream prior to release to the environment.

Comparability. An expression of the relative confidence with which one data set may be compared to another.

Completeness. A qualitative parameter expressing the percentage of measurements judged to be valid.

Compliance Assessment. A documented examination of a facility or an activity to verify compliance with requirements.

Compliance Assessment Checklist. A series of closed-ended questions designed to determine whether the assessed activity is in compliance with the applicable requirements.

Contamination. The presence of an unwanted substance in an area.

Contractual Quantitation Limit. The contractual quantitation limit (CQL) represents the lowest level of quantitation agreed on by the analytical laboratory and formally established in applicable contracts or work orders that the laboratory attests can be reliably achieved within contractually (or work order) established limits of precision and accuracy under routine laboratory operating conditions. The CQL is based on analytical experience and the data needs of individual projects; it represents the minimum acceptable standard against which analytical data will be judged. 
WHC-EP-0528-2

Curie. A unit of activity representing 3.7E+10 nuclear transformations per second.

Detection Limit. The smallest concentration of radioactive material in a sample that will yield a net count (above system background) that will be detected with a $95 \%$ confidence level.

$$
D L=\left[\left((4.6)\left(S_{b}\right)\right)+(2.72 / T)\right] /\left[(E)(V)(2.22 E+06)(Y)\left(e^{-(k)(d t)}\right)\right]
$$

where

$\mathrm{DL}=$ The detection limit as defined above ( $\mu \mathrm{Ci}$ per unit mass or volume) $S_{h}=$ The standard deviation of the background counting rate (counts per minute)

$T=$ The sample count time in minutes

$E=$ The counting efficiency (counts per disintegration)

$V=$ The sample size (in units of mass or volume)

$2.22 E+06=$ Number of disintegrations per minute per microcurie

$Y=$ The fractional radiochemical yield (when applicable)

$\mathrm{e}=$ The base of natural logs (approximately 2.718)

$k=$ The radioactive decay constant for the particular radionuclide

$d t=$ The elapsed time between sample collection (or end of sample collection period) and the time of counting.

Deviation. Deviation refers to a planned departure from established criteria that may be required as a result of unforeseen field situations or that may be required to correct ambiguities in procedures that may arise in practical applications.

Effective Dose Equivalent $\left(H_{E}\right.$ or $\left.E D E\right)$. The summation of the products of the dose equivalent received by specified tissues of the body and a tissue-specific weighing factor. This sum is a risk-equivalent value and can be used to estimate the health-effects risk of the exposed individual. The tissue-specific weighing factor represents the fraction of the total health risk, resulting from uniform whole-body radiation, that would be contributed by that particular tissue. The EDE includes the committed EDE from internal deposition of radionuclides and the EDE caused by penetrating radiation from sources external to the body; it is expressed in units of rem (or sievert).

Effluent. Any treated or untreated air emission or liquid discharge at a DOE site or from a DOE facility. The term includes onsite discharge to the atmosphere, lagoons, ponds, cribs, injection wells, French drains, or ditches. The term does not include solid wastes stored or removed for disposal or wastes contained in retention basins or tanks before treatment and/or disposal. 
Effluent Monitoring. The collection and analysis of samples or measurements of liquid and gaseous effluents for the purpose of characterizing and quantifying contaminants, assessing radiation exposures of members of the public, providing a means to control effluents at or near the point of discharge, and demonstrating compliance with applicable standards and permit requirements.

\section{Emission. See effluent.}

Environmental Monitoring. Environmental monitoring is the collection and analysis of samples or direct measurements (i.e., continuous monitoring) of environmental media. Environmental monitoring consists of two major activities: effluent monitoring and environmental surveillance.

Environmental Surveillance. The collection and analysis of samples or direct measurements of air, water, soil, foodstuff, biota, and other media from DOE sites and their environs for the purpose of determining compliance with applicable standards and permit requirements, assessing radiation exposures of members of the public and assessing the effects, if any, on the local environment.

Exhaust Stack. A building stack that vents air or gaseous material to the atmosphere.

Facility. A processing plant, tank farm, shop, laboratory, powerhouse, or laundry on the Hanford Site.

Flow Totalization. The cumulative measurement over time of the total quantity of a material in terms of mass or volume.

Gaseous Effluent. A gaseous or vapor substance discharged from a facility into the environment.

Gaseous Radioactive Effluents. Radioactive particles, mists, vapors, fumes, and/or gases contained or entrained in airborne effiuents.

HEPA. High-efficiency particulate air filter. To qualify as a HEPA, a filter must achieve an efficiency of $99.97 \%$ under laboratory conditions and 99.95\% after installation in the removal of airborne particulates of greater than $3 E-5 \mathrm{~cm}$ (0.3 microns) in size.

environment.

Liquid Effluent. A discharge of liquid waste from a facility into the

Nonconformance. A deficiency in characteristic, documentation, or procedure that renders the quality of material, equipment, services, or activities unacceptable or indeterminate. When the deficiency is minor, does not effect a permanent or significant change in quality if it is not corrected, and can be brought into conformance with immediate corrective action, it shall not be categorized as a nonconformance. However, if the nature of the condition is such that it cannot be immediately and satisfactorily corrected, it shall be documented in compliance with approved procedures and brought to the attention of management for disposition and appropriate corrective action. 
Precision. A measure of the repeatability or reproducibility of specific measurements under a given set of conditions. Specifically, it is a quantitative measure of the variability of a group of measurements compared to their average value. Precision is normally expressed in terms of standard deviation, but may also be expressed as the coefficient of variation (i.e., relative standard deviation) and range (i.e., maximum value minus minimum value). Precision is assessed by means of duplicate/replicate sample analysis.

Proportional Sampling or Monitoring. For continuous airborne effluents, the ratio of the sample flow rate (e.g., the flow through the filter) to the discharge flow rate is constant within acceptable limits. For continuous liquid effluents, the ratio of the sample volume to the discharge volume is constant. For batch releases, the ratio of the sample volume to batch volume is constant from batch to batch (this applies only to the final volumetric composition of the record sample as analyzed by the laboratory).

Quality Assurance. The total integrated quality planning, QC, quality assessment, and corrective action activities that collectively assure that data from monitoring and analysis meet all end user requirements and/or the intended end use of the data.

Quality Assurance Project Plan. An orderly assembly of management policies, project objectives, methods, and procedures that defines how data of known quality will be produced for a particular project, investigation, or monitoring program.

Quality Control. For the purposes of effluent monitoring, quality control refers to the routine application of procedures and defined methods to the performance of sampling, measurement, and analytical processes.

Radioactive Liquid Effluent. A liquid effluent that has a reasonable potential for containing radioactive materials in quantities such that the annual average concentration is equal to or greater than the maximum contaminant leve1.

Record Sample. A representative sample collected in a sampling system for laboratory analysis used as a basis for reporting to DOE, facility operations, and Safety the amounts of contaminants released to the environment.

Reference Samples. A type of laboratory QC sample prepared from an independent, traceable standard at a concentration other than that used for analytical equipment calibration, but within the calibration range. Such reference samples are required for every analytical batch or every 20 samples, whichever is greater.

Representativeness. The degree to which data accurately and precisely represent a characteristic of a population parameter, variations at a sampling point, or an environmental condition. Representativeness is a qualitative parameter that is most concerned with the proper design of a sampling program.

Sample. A physical specimen of air or water. 
Sampling Schedule. A description of routine sampling necessary to support the effluent monitoring program. Sampling schedules specify the effluent, location, size, type, and frequency of samples to be collected.

Sampling System. Instrumentation and equipment that remove a part of a Tiquid or airborne waste stream for subsequent quantitative determination of a stream parameter. The system generally employs such devices as filters, other sample collection media, or effluent traps of some kind. A continuous sampling system removes a part of the stream continuously except during sample change, maintenance, repair, or other necessary outages. A grab sampling system removes an instantaneous part of the stream or removes a part of the stream over a time period.

Validation. A systematic process of reviewing a body of data against a set of criteria to ensure that the data are acceptable for their intended use. Validation methods may include review of verification activities (i.e., QC program), editing, screening, cross checking, historical trending, and technical review.

Verification. The process of determining whether procedures, processes, data, or documentation conform to specified requirements. Verification activities may include inspections, audits, surveillances, or technical review. 


\section{WHC-EP-0528-2}

This page intentionally left blank. 


\subsection{REFERENCES}

Beres, D. A., 1990, The Clean Air Act Assessment Package-1988 (CAP-88), A Dose and Risk Assessment Hethodology for Radionuclide Emissions to Air, Vols 1-3, U.S. Environmental Protection Agency, Washington, D.C.

BHI, 1995, Radiological Control Work Instructions, BHI-SH-04, Bechtel Hanford Incorporated, Richl and, Washington.

DOE, 1988, General Environmental Protection Program, DOE Order 5400.1, U.S. Department of Energy, Washington, D.C.

DOE, 1990, Radiation Protection of the Public and the Environment, DOE Order 5400.5, U.S. Department of Energy, Washington, D.C.

Ecology, EPA, and DOE, 1990, Hanford Federal Facility Agreement and Consent Order, as amended, Hashington State Department of Ecology, U.S. Environmenta1 Protection Agency, and U.S. Department of Energy, Olympia, Washington.

EPA, 1983, Interim Guidelines and Specifications for Preparing Quality Assurance Project P7ans, QAMS-005/80, EPA-600/4-83/004, U.S. Environmental Protection Agency, Washington, D.C.

EPA, 1989, "National Emissions Standards for Hazardous Air Pollutants," Title 40, Code of Federal Regulations, Part 61, U.S. Environmental Protection Agency, Washington D.C.

EPA, 1991, "Quality Assurance Methods," Title 40, Code of Federal Regulations, Part 61, Appendix B, Method 114, U.S. Environmental Protection Agency, Washington, D.C.

Napier, B. A., R. A. Peloquin, J. V. Ramsdell, and D. L. Strenge, 1988, Hanford Environmenta7 Dosimetry Upgrade Project: GENII - The Hanford Environmental Radiation Dosimetry Software System, PNL-6584, Pacific Northwest Laboratory, Richland, Washington.

PNL, 1991, Analytical Chemistry Laboratory Manua7, PNL-MA-597, Pacific Northwest Laboratory, Richland, Washington.

WAC 246-247, 1994, "Radiation Protection - Air Emissions," Washington Administrative Code, as amended.

WHC, 1991, Effluent Monitoring Program - 300, 400 and 1100 Areas, WHC-IP-0704, Hestinghouse Hanford Company, Richland, Washington.

WHC, 1992a, Scheduled Radiation Survey and Task Description for T Plant, T-H-01, Hestinghouse Hanford Company, Richland, Washington.

WHC, 1992b, Task Description for 340 Waste Handling, Occupational Health and Safety Scheduled Radiation Survey and Task Description, Task No. J-W005, Survey No. 911562, Westinghouse Hanford Company, Richland, Washington. 
WHC, 1993, Health Physics Procedures, WHC-IP-0718, Hestinghouse Hanford Company, Richland, Washington.

WHC, 1995a, Quality Assurance Program Plan for Radionuclide Airborne Emissions Monitoring, WHC-EP-0536-2, Westinghouse Hanford Company, Richland, Washington.

WHC, 1995b, Statement of Work for Services Provided by the Waste Sampling and Characterization Facility for Effluent Monitoring, WHC-EP-0835,

Westinghouse Hanford Company, Richland, Washington.

WHC, 1995c, Effluent Monitoring Procedures, WHC-EP-1066, Westinghouse Hanford Company, Richland, Washington.

WHC-CM-1-3, Management Requirements and Procedures, Westinghouse Hanford Company, Richland, Washington.

WHC-CM-3-5, Document Contro7 and Records Management, WHC-CM-3-5, Westinghouse Hanford Company, Richland, Washington.

WHC-CM-4-2, Quality Assurance Manual, Westinghouse Hanford Company, Richland, Washington.

WHC-CM-5-4, Analytical Chemistry Services Laboratories - Operating Instructions, Westinghouse Hanford Company, Richland, Washington.

WHC-CM-7-5, Environmental Compliance Manual, Westinghouse Hanford Company, Richland, Washington.

\section{Procedures}

Westinghouse Hanford Company, Richland, Washington:

LA-218-412, 1993, Tritium Analysis on Silica Gel by Liquid Scintillation Counting

LA-220-406, 1994, Strontium-89 and 90 in Aqueous Samples by SR-Spec Separation

LA-220-407, 1994, Measurement of Self-Absorption of Beta Radiation for 90 SR Determinations

LA-508-051, 1990, Alpha Energy Analysis Using the Canberra Jupiter Systems

LA-508-110, 1994, Operation of the Tennelec L/B 5500 ATpha/Beta Counting System

LA-508-472, 1995, Alpha Energy Sample Processing Using A7pha Management Software on the Genie System

LA-508-471, 1995, Alpha Energy Data Acquisition and System Checkout Using Alpha Management Software on the Genie System

LA-508-481, 1995, Gamma Energy Analysis Using PROcount Software 
WHC-EP-0528-2

LA-508-415, 1995, Operation of the Protean 2-Inch Alpha/Beta Counting System

LA-508-421, 1995, Operation of the Tri-Carb Model 2500 TR Liquid Scintillation Analyzer

LA-542-401, 1993, Electrodeposition of Actinides - WSCF

LA-548-411, 1993, Preparation of Mounts for Liquid Scintillation Counting - WSCF

LA-548-421, 1995, Preparation of Sample Mounts for Gamma Energy Analysis

LA-548-442, 1993, Preparation of Quarterly Filter Composites for Gamma Analyses

LA-549-412, 1994, Dissolution of Versapor Type Filters - WSCF

LA-613-411, 1994, Determination of Promethium 147 in Effluent Water Samples by Solvent Extraction and LSC - WSCF

LA-925-407, 1994, Uranium by Laser Induced Kinetic Phosphorescence

LA-943-424, 1994, Americium and P7utonium TRU-SPEC Separation and Neodymium Fluoride Precipitation Plating

L0-150-133, 1994, Processing Record Stack and Red-Bordered (Emergency) Air Samples

L0-150-415, 1994, Instrument Standards Counting Schedule - WSCF Nuclear Spectroscopy and Air Sample Laboratories

LQ-508-405, 1995, Gamma Energy Ana7yzer System Ca7ibration Using Procount Software

LQ-508-002, 1994, Calibration Guidelines for Window-Type Gas Flow Alpha/Beta Proportional Counters

LQ-508-005, 1990, Calibration of Beta Detectors for SR 90 
WHC-EP-0528-2

This page intentionally left blank. 


\section{DISTRIBUTION}

\section{Number of copies}

ONSITE

1 U.S. Department of Energy, Field office Richland

D. C. Ward

H. M. Rodriguez

33 Westinghouse Hanford Company

J. M. Barnett

S3-95

J. A. Bates

H6-22

R. J. Boom

S3-95

A. K. Dasgupta

S3-28

W. E. Davis

H6-20

L. P. Diediker (2)

S3-95

D. L. Dyekman

$\mathrm{XO}-21$

J. J. Dorian

$53-24$

D. G. Farwick

T. P. Frazier (10)

T6-03

B. P. Gleckler

S3-95

L. D. Kamberg

S3-95

R. E. Johnson

H6-26

P. J. Martel1

S3-95

S. M. McKinney

S3-95

J. K. Perry

D. G. Ranade

S3-95

$\mathrm{H} 6-20$

$\mathrm{H} 6-26$

L. W. Vance

T6-03

Central Files

A3-88

OSTI (2)

DOE Public Reading Room

E6-44

Hanford Technical Library

H2-53

P8-55 


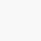

